\title{
CLAIMING SELF: \\ THE ROLE OF AFRIKOLOGY IN \\ SOCIAL TRANSFORMATION
}

Baba AO Buntu

Visiting Lecturer

Department of Christian Spirituality, Church History and Missiology

University of South Africa

\begin{abstract}
A number of crises - including political, economic and philosophical crises - have become intrinsically associated with Africa. This article argues that the most alarming crisis might be located in a worldview where Africa's self-determination has become absent. The challenge of repositioning Africa and deconstructing its ontological base represents an opposition to Academia, institutions and scholarship, where preconceived ideas of Africa as 'the other' have become dominant. To this effect, the need for reclaiming a collective sense of Self is deemed necessary as a premise for authentic change. The field of theology, with its focus on relations between woman/man, God and nature, needs to be challenged on this. By examining the role of African epistemology as integral to liberating strategies, the article advances Afrikology as a transdisciplinary and decolonial solution to social transformation.
\end{abstract}

Key Words: Afrikology; African Epistemology; Cultural Education; Afrocentricity; Social Transformation; Decolonial Theory

\section{Introduction}

In her own unique way, Africa is raising fundamental questions - especially on the invading world religions such as Christianity, Islam and Buddhism. These religions owe Africa an explanation. Rather than (continue to) exploit and simply assume Africa's hospitality, these religions must argue their case. Why must Africa continue to be host to them given the tremendous problems and ambiguities associated with their presence in Africa, for example? (Maluleke 1996:16).

Many of Africa's present theological discourses have developed as a result of, or in response to, domination and power from external sources, seeking to win the obedience by an indigenous followership. The various strands of missions to convert Africans to Christianity and Islam, in particular, have ravished the African continent by means of invasion, war, coercion, cultural imperialism, ethnocentric ideology, identity theft, hegemonic orthodoxy and colonial power constructs.

More than a theological discussion in itself, this chapter will outline some considerations for scholars interested in explaining the relations between woman/man, God and nature (often regarded to be the three main subjects of theology), with a perspective that envisions African liberation. 


\section{Crisis Impacting on the African Global Community}

It can be argued that Africa - and the African Diaspora - suffers from several crises. The political and economic situations most African communities find themselves in today are a far cry from the visions articulated by Pan-African leaders in history, such as Kwame Nkrumah, Thomas Sankara and Marcus Garvey. Perhaps appearing to be of lesser importance, there is also a philosophical crisis; the experience of modernity has been characterised by cultural and spiritual poverty. Africa has paid a high price for westernised development and democracy, and continues to struggle to reassert its self-determination. The many attempts to enable Africa to recover from the multiple layers of pain unleashed on her have made it appear as if there is something wrong with Africa as a continent. An image of Africa as being intrinsically dependent on foreign influence and domination has been well established over many years. However, the real problem might be how we understand, or misunderstand, Africa, not the continent itself.

Within African epistemology, emphasis has been engraved on learning processes, in particular imparting of wisdom and skills from generation to generation. As westernized modernity has reshaped and corrupted many of the cultural foundations of traditional society, important information and institutions for social cohesion have deteriorated. These destructive changes - sometimes manifesting as cultural amnesia, self-negation and spiritual confusion in people across Africa and the African Diaspora - call for responses to revive and reposition culture as a tool to solve current social challenges.

This article explores the importance of self-consciousness as a concept of collectivism within an African-centred perspective; a self-consciousness which works towards the common good, not for individual gains: a process focused on fundamental changes within individual, group, family, community and nation as part of broad-based transformation; changes which demand groundbreaking solutions in combining ideas and actions.

The article argues the necessity for developing cognitive processes of self-consciousness, located in a drive for collective efforts towards social transformation informed by Africa's past, present and future. Afrocentricity, informing multi-disciplinary research, discourse and applied knowledge will be examined as an academic field, and praxis, which can become accentuated through Afrikology.

The need for social transformation for Africans and African descendants resonates with a vision that has been called and reformulated repeatedly, especially in response to the enslavement, colonialism and imperialist oppression of Africa and Africans. Hence, this article is motivated by the search for a scholarship that is not defined by its neutrality, observer-status and analytical diagnoses, but an action-orientation whose attributes are marked by both tearing down oppressive obstructions and setting up functional structures for new realities to take shape.

Mignolo's (2009:7) view on honest scholarship is helpful here. He writes from a position which acknowledges that the academic world has been built on a Western premise, filtered through a colonial matrix of power, conceptualised through a racial system of social classification and compartmentalised through a remapping of the world into first, second and third. Mignolo identifies two emerging directions of what he calls 'epistemic disobedience' within global knowledge production and social development. He refers to one as de-westernization - which is described as a counter-movement within a capitalist economy, where the rules are no longer defined by Western players and institutions - and the other as a de-colonial position - which include various ideological streams having in common that 
they are based on a definitive rejection of accepting the role as 'the other', and a reorientation of Euro-centred modernity.

As argued by Ndlovu-Gatsheni (2013:11), “...endogenous and indigenous knowledges have been pushed to the margins of society. Africa is today saddled with irrelevant knowledge that disempowers rather than empowers individuals and communities." In this light, the need for a decolonial position becomes critical and represents a challenge to discourses of knowledge, including that of theology.

\section{The Need for Social Transformation}

There is a qualitative difference between transformation and change. All transformation is change, but not all change is transformation. Change can be achieved by approaching a problem differently or finding ways to overcome or cope with the effects of its existence. Transformation affects all components of the structure it seeks to change by creating a whole new form, function or structure (ibid.). It is a revolutionary stance, which, naturally will be opposed by the power structures that benefit from the existence of the problem.

The human cost for prolonged domination manifests on multiple levels: psychologically, breakdown of family structures, cultural dislocation, systemic imbalances and social disintegration, to name a few. The devastating impact of invasions, enslavement, colonialism, external domination and internal erosion has developed stagnancy which calls for social transformation.

It is well-documented that Europe - and the global North - through its political and economic expansion over many years, established a culture of political imbalance and inequality, to the detriment of the global South in general, and to Africa in particular (Rodney 1981; Chinweizu 1987; Ephraim 2003). Identifying a strong relationship between culture, ideology and behaviour, Ani (1994) traces the origins of the values behind European expansion to cultural ideas in which violence features prominently. In a sense, a culture that justifies and legitimises violence in a broad sense has come to characterise how globalisation is experienced by the majority of world citizens.

Globalisation has been a dominating feature in international relations of the twentieth century. Duru (2012) has described one of the major impacts of globalisation on African states and people to be the development of a self-image characterised as a marginalised, devalued and dominated victim, barred from real power in the international arena.

Odora-Hoppers and Richards (2011:88) describe three epochs of dehumanising globalisation: Firstly, Europe's colonisation of societies, communities, ideas and land, a process within which the West was able to cement its power through physical domination and control; secondly, the development of Eurocentric modernization paradigms, which represented ideological violence through conformity of standards and extermination of diversity and thirdly, the metaphor of 'free trade', a paradoxical paradigm dressed up in the possibilities of liberalisation, yet ensuring a one-dimensional power imbalance through protectionism.

Psychiatrist Frantz Fanon, psychologist Dr Na'im Akbar, anthropologist Marimba Ani and literary critic Chinweizu have all contributed to a scholarship that has demonstrated the mental effects of oppression on the African psyche, personality, behaviour and socialisation. Emphasising the importance of knowing one's history, Professor Amos N Wilson (2002:22) has described the collective case of most Africans as being one suffering from 
amnesia; not remembering history, not remembering culture, not remembering a sense of self:

Amnesia means an undiscovered self, an emptiness, a self incapable of self-understanding its own motivations, a self incapable of self-direction and self-determination, a reactionary self, a self that does not understand others or the world in which it exists $-a$ fatalistic externalized self. To rediscover one's history is not only an act of selfdiscovery; it is an act of self-creation - a resurrection from the dead, a tearing away of the veil, a revelation of the mystery.

As the Self is seen as the central agent to carry out sustainable change, failure to empower it will have detrimental results. The many waves of conquest and domination meted out against Africa and Africans, having taken place over hundreds of years, have left a legacy of servitude and powerlessness. What power should the African seek then, we might ask. Anthropologist Marimba Ani asserts that a diametrical difference in understanding power can be identified within African and European culture (Ani 1994). Whereas a European definition largely equates power with the ability to dominate, an African-centred definition explains power as the ability to do, create and shape. Hence, an African counter-strategy, as it relates to power, is not a replication of European oppression, but a re-creation of cultural legacies interpreted for, and applied to, contemporary needs.

In post-colonial Africa, education has been advanced as a solution to effective development. Nabudere (2011) asserts that the models for academic education Africa has adopted have proved to be unsuitable for Africa's needs, as they have failed to respond to the particular challenges Africa is facing. An African-based epistemological foundation, according to Nabudere, is a prerequisite to the production and development of knowledge.

The challenges impeding on education in Africa stem from the many waves and layers of invasion, domination, conquest, destruction and disempowerment. But the problems also derive from the inability on the part of African nation states to build sustainable counterstructures with autonomous governing systems. A perpetual dependency on the West has been the typical scenario in African democracies since the 1960s. This has led to a sense of African pessimism and, possibly, great doubts as far as independent initiatives are concerned. Steve Biko (2004:51) encouraged Africans to reject Western values and, by doing so also:

...rejecting those things that are not only foreign to us but that seek to destroy the most cherished of our beliefs - that the corner-stone of society is man himself - not just welfare, not his material wellbeing but just man himself with all his ramifications.

Burrell advances a theory of how Black Inferiority has been developed as a brand through a history laden with racism and colour-consciousness. By ascribing to stereotypes of Black behaviour and a multitude of dysfunctional social institutions, in which violence and disintegration form an integral part, the self image of Black people has become so low that hatred of self and others have become a norm. This assertion is supported by De Gruy Leary (2006), who in her book Post-Traumatic Enslavement Syndrome, examines how injustices meted out against Africans over many generations during enslavement and colonialism manifest as a legacy of reproduced social ills.

As challenges confronting African development take place on several levels simultaneously - psychological, economic, political, social, cultural and spiritual levels, to mention some - a picture emerges in which prolonged oppression can be said to have its own educational function; a learnt weakness. This is what Fanon (1965:149) has described as "traditional weakness, which is almost congenital to the national consciousness of under- 
developed countries". When these values, worldviews and assumptions become repetitive and an integral part of human orientation, we can say that they take on a cognitive character. In other words, weakness, disability and disenfranchisement become more than just a description of challenges encountered, they come to define reality; an accepted reality.

As weakness is learnt, so is strength. A visionary understanding of possibilities can be transmitted through educational processes. Such a process will have as its objective to expose African people to knowledge and skills in a way that brings about change, first and foremost in their respective communities. We are talking here of re-installing a culture of applied learning; a three-phase process where people, after (1) learning (the learnt ignorance and misinformation) need to go through a stage of (2) un-learning (dismantling the misinformation) before they can embrace (3) re-learning (replacing wrong information with correct information). This process, actively engaging the Self, attends to the collective needs and interests of Africans and African descendants, enabling them to act both locally and globally.

\section{Solutions Embedded in Afrikology}

Afrikology represents a platform that is both broad enough to provide space for paradigmatic diversity and focused enough to be a vehicle for practical change. The concept of Afrikology, as multi-disciplinary research, discourse and applied knowledge becomes an academic field (and praxis) which fuses the gathering of data with the application of knowledge in a complementary process. As outlined by Ntate Kgalushi Koka (2002:10), Afrikology envisions a dedicated African scholarship:

(...) based on Afrocentric studies in socio-economics, philosophy, religion and spirituality, governance, technology and science - dedicated to the development and advancement of Afrika and her people, and competent of representing and presenting Afrika in forums of nations.

There is a need for clarity of purpose among African knowledge producers. Nyasini (1997:126-128) accuses African intellectuals of 'cultural betrayal' and 'self-dehumanization' as, in his view, “...there is no race on earth that abhors its own culture and is so easily prepared to abdicate it and flirt with experimental ideas which promise no more than vanity, to a large extent, like the African race..." Makgoba (1997:205) presents a similar view where he notes that knowledge about Africa "propagates Western culture," "perpetuates an inferiority complex" and "disrupts [African] unity". Since African knowledge is politicised and the idea of an 'organised Afrocentric community' is feared, he concludes that "we are incapable of being masters of our own destiny" (ibid). Mbigi (1997:37) has presented a rather different view, in which he argues that African wisdom - exemplified by the concept of Ubuntu ("I am because we are. I can only be a person through others") - can, and must, be integrated into modern, corporate and civil leadership and management structures. He asserts that, by drawing from African cultural concepts, African leaders must "...have a sense of legacy and selflessness if they are going to define the ultimate mystery and meaning of human existence to their followers" (ibid).

Transdisciplinary research offers a new dimension to the process of knowledge production by seeking to transcend and integrate disciplinary paradigms in order to respond to socially relevant - and not purely academic - issues (Pohl 2011). By broadening the academic research scope, transdisciplinarity is oriented towards problem fields in the life- 
world (Hirsch Hadorn et al. 2008) - a position which is articulated in the observation, "the world has problems, universities have departments" (Brewer 1999:328). This approach is well suited to situations where "the concrete nature of problems is disputed, and when there is a great deal at stake for those concerned by problems and involved in dealing with them" (Pohl \& Hirsch Hadorn 2006:20). Examples of such problem fields include migration, violence, health, poverty, global environmental change and cultural transformation processes; challenges with particular impact on people's social well-being.

A transformative approach must dare to look beyond the obvious, courageously alter and replace conventions and strongly believe in the possibility of new realities. In the view of Nicolescu (2002), transdisciplinarity, as an approach, starts with a rejection of all dogma, ideology and closed systems of thought. A transdisciplinary culture, to him, is therefore a culture of questioning, accompanied by responses that are seen to be temporary. A weakness in Nicolescu's writing is that he advocates that transdisciplinary must go beyond the disciplines, yet his method depends on the very disciplines he refutes. Nabudere (2011:38), recognising this, suggests an Afrikological approach characterised by complimentarity and interconnectedness: ..."a wholeness where all reality can converge and reconcile humankind with itself"'

Nabudere (2011:159) advances Afrikology as an authentic platform with academic aspirations, drawing “... together all the strands achieved from all the different perspectives of the African worldview (...) and uses this to critique Eurocentric mystification". As a term Afrikology encapsulates both the gathering of data and the application of knowledge as complementary processes. This, as part of an African-centred approach, represents a platform for multidisciplinary research, discourse and applied knowledge and adheres to what Asante has described as the necessity to "... abandon ethnocentric and racist systems of logic and, therefore, to place the undiscussed in the center of discourse" (Asante 1990:140). Thus, as a philosophy of education, Afrikology transmits theoretical knowledge into both cognitive and pragmatic currencies.

The reluctance demonstrated in Afrikology to be confined within Academia easily relates to transdisciplinary research as an orientation towards problem fields in the life-world rather than attempting to suit problem analyses within established disciplines (Hirsch Hadorn et al. 2008). Also, Afrikology carries within it notions of critical inquiry and fearless aspiration for new paradigms, positioning epistemic disobedience at the core of its operations (see Mignolo 2009).

\section{Repositioning Africa}

The dehumanisation of African people forms part of the challenge to which African education must respond - not only as an emotionally charged reaction, but as a strategic, well-planned effort towards building an empowered African continent. Many of the pyramids in ancient Egypt had the inscription "Know Thyself", which pointed to the centrality of self-knowledge in African culture: "...to be conscious was to be alive and to be human. The greater the consciousness, the higher was the expression of one's humanity" (Akbar 2007:vi). This notion also carries with it an understanding that educational processes that fail to create consciousness and self-knowledge are detrimental to human development.

Restoration of Self, as a collective process, must be anchored in a learning process. In fact, all tenets of Afrikology; research, knowledge production and praxis must have learning at the centre and manifest in the collective self. Engraved in African epistemology 
is a strong emphasis on learning processes, in particular, the imparting of wisdom and skills from one generation to the next (Nabudere 2011). As Westernised modernity has reshaped and corrupted many of the cultural foundations of traditional society, important information and institutions for social cohesion have deteriorated (Asante 2003).

In her analyses of European behaviour and thought, Ani (1994) finds that European traditions negate - or, at the very least, sceptically question - the spiritual world while Africa is based on it. In the African world, a symbiotic relationship exists between religion and culture. Religion is inextricably linked to culture, exerting enormous influence on human beings; and at the same time, animating both his/her personal and communal activities in the society. Thus, African Traditional Religion is 'inherently holistic' (Igwegbe 1995). This sense of wholeness is an important aspect of African life. The religion permeates almost every crucial aspect of the African life, namely: marriage, birth, naming ceremony, initiation rite, illness, healing, and death (ibid.). In African Traditional Religion one could hardly distinguish the secular from the sacred, the religious and the nonreligious, the spiritual and the material areas of life (Mbiti 1989).

As pointed out by Boateng (1996), the role of traditional education is to bridge the gap between the young and the old generation. Western education has transmitted a culture in stark opposition to what African culture would have sought to transmit, and, largely, served as an obstacle to the process of cultural transmission and intergenerational communication.

Armstrong (1975) also observes that in an African worldview, energy, rather than matter and dynamic, not static being, constitute the true nature of things. This view, however - as would be argued by Ani (1994) - fails to acknowledge that African epistemologies are rooted in a symbiotic duality between scientific and metaphysical observations. This is an interesting reminder, especially in response to the somewhat shallow assumption that African knowledge is purely metaphysical. Rather, one could say that African science is rooted in a spiritual context. Mbiti (1989:1-2) explains the universe of Africans to be deeply religious, to such an extent that "... to ignore these traditional beliefs, attitudes, practices and symbolic values can only lead to a lack of understanding of African behaviour and problems."

Boateng (1996) views African culture to be of high educational value. The role of traditional education, he asserts, is to bridge the gap between the young and the old generation. Western education - which did not consider cultural transmission as a goal of the educative process - has, largely, been an obstacle to the process of cultural transmission and intergenerational communication. Moreover, Boateng sees African traditional education as intergenerational communication which refers to transmission and continuous preservation of the values and traditions of a society from one generation to another. This transmission ensures peaceful transition from youth to adulthood and creates understanding of the roles of each generation in the society.

Some common ways of facilitating this transmission include oral literature (fables, myths, legends, proverbs) and secret societies (initiation). With particular reference to initiation, several psychic and social challenges were addressed and responded to, such as gender identity, relation to parents, cognitive development and psychological grounding. Young women and men were guided from childhood to adulthood with a distinct way of leaving childish and irresponsible behaviour behind. The handing down of technical skills and know-how would also follow a similar, inter-generational pattern.

Such a process of Afrikological praxis would start on individual level and then, through youth and family members, reach community levels as it expands. It would make every 
participant both a student and a practitioner. Education as a field of learning and application must enable students to gain a strong sense of self. This means that it needs to start by locating the students in their own history: past, present and future. Students must experience themselves as change agents, not mere objects of a 'repeat-after-me' indoctrination. The focus of such educational programmes must include vocational training, capacity building and leadership development located in African history, culture, science and wisdom.

This means a radically different perspective on education as a liberating and enabling process. The goal must be to implement a reorganised educational system which is suitable and appropriate to the needs of young African people. In its initial stages, this process can be initiated at community level, with an emphasis on alternative and complementary education: Saturday schools, weekend camps and afternoon classes.

True to a popular saying, 'you cannot teach what you do not know,' there is a critical need to develop teachers and trainers with adequate information. The starting phase must include teacher-training and the development of relevant teaching material. As there are many African communities around the world who have embarked on this, networking and sharing of the best practices will be of key importance.

Prosperity and power are linked closely to wealth creation, which again requires cultivation of entrepreneurial creativity. The development of businesses, new markets, technological inventions and new systems for both accumulation and distribution of wealth must be prioritised areas. As a basic principle of a liberating strategy, every community member must take part in some form of productive resource development activity.

The discipline of theology, from Western and Islamic points of view - and often in the works articulated by African theologians themselves - has, rather arrogantly, refused the possibility of indigenous religious systems to be validated with their own, independent theology. Africa, as a location, is positioned as a site in need of external help to realise its spiritual path. To the extent that Africa is given spiritual value, it is often seen through a lens of infantilised imagery, restricted to quite blurry notions of, for example, Ubuntu, values of common humanity and forgiveness; in other words, a rather child-like mysticism, not 'real' theological positions.

These misconceptions should be challenged, first and foremost by representatives of African communities of spiritual practitioners themselves. As pointed out by Mignolo and Tlostanova (2009:144), decolonial thinking and action must be "...led and created by the social actors Frantz Fanon referred to as "les damnés de la terre"; all those humiliated, devalued, disregarded, disavowed, and dealing with the "colonial wound". The myriad of cultural tools expressed throughout African traditions can be revived, re-interpreted and reapplied in accordance with contemporary relevance. A symbiotic relation between old and new will be beneficial. Spiritual strength, as articulated in the order of Ma'at, the reclaiming of an authentic African history and the centring of African values, location and agency, will make African modernisation an ideal, not a threat.

\section{African Epistemology as Integral to African liberation within Theology}

This chapter opened by acknowledging the many crises confronting Africa, and the realisation that scholarly disciplines, including that of theology have contributed to - and are affected by - this. Yet, a bold stance would force us to reassert Africa not just as a space of crisis, but a continent with possibilities of not only responding to crises, but overcoming 
them, rising from them and transforming with the intention never to revert to injustices of the past.

We have outlined a number of challenges facing Africans and emphasised the need to locate solutions in a self-affirming, cognitive process which is geared towards collective development and grounded in an African worldview. The field of theology in Africa and its Diaspora must expand its horizon and include attention to liberating education; Dr Akbar (2007:2-15) has outlined four main functions of education, by which we can evaluate its effectiveness:

- to provide identity; as a process in which the individual is assisted in achieving full humanity;

- to transmit a legacy of competence; as a process of self-affirming information for the individual to see herself/himself as part of a history of innovation and possibilities;

- to transmit acquired immunities; as a process of resilience for the individual to adopt skills to be implemented when faced with threats, opposition and attack;

- to develop a shared vision; as a process in which the individual is involved in a common destiny where she/he can achieve his/her highest potential as part of a community of excellence.

We have described Afrikology as an African-centred epistemology for social transformation, with the ability to carry out production and dissemination of knowledge simultaneously. This entails an expectation that African theologians position African challenges and solutions unapologetically, as the focal point of their work. Empowered with a critical and de-colonial apparatus, such theologians must advance an Afrikology that develops:

- Resilience towards legacies of oppression, to rebuild and develop autonomous educational structures;

- Access to - and implementation of - knowledge embedded in indigenous wisdom and science;

- Dissemination and positioning of own pools of knowledge, to enable interaction with other systems of knowledge on equal terms.

Odora-Hoppers (1998:184) reminds us that just saying we want transformation does not mean it actually takes place. Our abilities to analyse, choose and sacrifice might already have been wired in such a way that we keep on blindly paving roads that do not present sustainable solutions, but become repetitions of what we actually wish to change:

If education is the mirror of society, then there is obviously an urgent need to yet define the form and nature of this 'society'. If education's role is to connect a learner with his/her heritage, then there is another urgent need to define whose normative heritage is being transmitted in present education practices.

The crises we seek to overcome are not only of African importance. The whole world community suffers from the imbalanced nature of globalisation. As emphasised by OdoraHoppers and Richards (2011:93), the age of the 'positivist illusion' - stuck in the enslaving idea of universal determinism and linear confines of rationality - must be exposed and broken down, and space must be cleared to include metaphysics and indigenous knowledge. It is within this project of deconstructing ideas, decolonising knowledge and re-asserting presence that Afrikology appears as a position in line with Mignolo's (2009) 'epistemic disobedience'. Afrikology activates a process of de-westernization and refuses the African to appear as 'the other' in her/his own view of the world. It accentuates an understanding of 
a collective Self in which determination of location, agency and possibilities are drawn from within.

In specific relation to the field of theology, Maluleke (1996:17) has suggested "...a major shift in focus from so-called global theology issues to the no less complex and daunting African issues in theology". He recommends that African thinkers, scholars and practitioners, after frantically having attempted to align themselves with imposed knowledge, should focus now on the "...ability to drink from our own wells" (ibid). This leaves a challenge to embark on a project of decoloniality which is geared towards a transdisciplinary (and not inter-disciplinary) interrogation, going beyond the existing disciplines, rejects 'disciplinary decadence' (Gordon 2006) and aims to un-discipline knowledge (Walsh et al. 2002).

African traditional religion does not have to justify itself in relation to theology. The field of theology does not belong to Western or Middle Eastern institutionalised schools of thought. Rather, African religion must dare to articulate and affirm its own, independent theology and position itself in a balanced exchange of reason with other religious systems. For this to be an authentic process, a de-colonial shift of Afrikology must take place, spearheaded by scholars who represent the experience of the colonial wound.

On closer examination, the most critical crisis of Africa may not be its actual statistics of failed economic development or democratic governance, but the dominant worldview that has been created of Africa as incapable of self-determined transformation, and the paralyzing loyalty that many African scholars demonstrate to externally located knowledge and worldviews. The African concept of 'Self' is not merely a notion of individuality, but, rather a collective focus where past, present and future interact. The extent to which African scholarship, innovation, education and politics will be able to centre itself around an authentic knowledge of Self is what will define whether social realities can be transformed sustainably.

\section{BIBLIOGRAPHY}

Akbar, N 2007. Know thyself (4th ed.). Tallahassee, FL; Mind Productions \& Ass.

Ani, M 1994. Yurugu: An Afrikan-centered Critique of European cultural thought and behavior. Washington, DC: Nkonimfo Publications.

Armstrong, RP 1975. Wellspring: On the myth and source of culture. Berkeley: University of California Press.

Asante, MK 1990. Kemet, Afrocentricity and knowledge. Trenton, NJ: Africa World Press.

Asante, MK 2003. Afrocentricity: The theory of social change. Revised ed. Chicago, Ill.: African American Images.

Biko, S 2004. I write what I like. Johannesburg: Picador/Macmillan.

Boateng, F 1996. African traditional education: A tool for intergenerational communication. In Asante, MK \& Asante, KW (eds.), African culture: The rhythms of unity. New Jersey/Asmara: Africa World Press.

Brewer, GD 1999. The challenges of interdisciplinarity. Policy Sciences, Vol. 32:327-337.

Chinweizu 1987. Decolonising the African mind. Lagos: Pero Press. 
Degruy Leary, J 2005. Post traumatic slave syndrome: America's legacy of enduring injury and healing. Milwaukie, Oregon: Uptone Press.

Duru, EJC 2012. Globalization and African Self-Determination. In International Journal of Humanities and Social Science, 2 (5):157-161.

Ephraim, CW 2003. The pathology of Eurocentrism: The burden and responsibilities of being black. Trenton/Asmara: Africa World Press.

Fanon, F 1963. The wretched of the earth. New York: Grove Press.

Gordon, L 2006. Disciplinary Decadence. Living Thought in Trying Times. London: Paradigm Publishers.

Hirsch Hadorn, G, Hoffmann-Riem, H, Biber-Klemm, S, Grossenbacher, W, Joye, D, Pohl, C, Wiesmann, U \& Zemp, E 2008. The emergence of transdisciplinarity as a form of research. In Hirsch Hadorn, G, Hoffmann Riem, H, Biber-Klemm, S,

Grossenbacher, W, Joye, D, Pohl, C, Wiesmann, U \& Zemp, E (eds.), Handbook of Transdisciplinary. Research Springer: Dordrecht, pp. 19-39.

Igwegbe, OI 1995. Sacramental theological thinking in the African symbolic universe: Affinities with John Henry Newman, Frankfurt am Main: Peter Lang.

Koka, K 2002. Afrikology: The logical study of Afrika (in its totality). Johannesburg: Institute of Afrikology.

Makgoba, MW 1997. Mokoko, the Makgoba affair: A reflection on transformation. Florida Hills: Vivlia Publishers and Booksellers.

Mbigi, L 1997. New life for a new year. Sawubona, December 1997:37.

Maluleke, TS 1996. Black and African Theologies in the New World Order: A Time to Drink from our Own Wells. In Journal of Theology for Southern Africa 96 (November 1996) 3-19.

Mignolo, WD 2009. Epistemic disobedience, Independent thought and de-colonial freedom. In Theory, Culture \& Society, Los Angeles, London, New Delhi, and Singapore: Sage 26 (7-8):1-23.

Mignolo, WD \& Tlostanova, M 2009. Global Coloniality and the Decolonial Option. In Kult 6-Special Issue. Epistemologies of Transformation: The Latin American Decolonial Option and its Ramifications. Roskilde University: Department of Culture and Identity, p. 130-147.

Mbiti, JS 1989. African religions and philosophy. Oxford/Portsmouth/Ibadan/Gaborone: Heinemann.

Nabudere, D.W. 2011. Afrikology, philosophy and wholeness: An epistemology. Pretoria: African Institute of South Africa.

Ndlovu-Gatsheni, S 2013. Why Decoloniality in the $21^{\text {st }}$ Century? In The Thinker, Vol. 48:10-15.

Nicolescu, B 2002. Manifesto of transdisciplinarity. New York: SUNY

Nyasini, JM 1997. The African psyche. Nairobi: University of Nairobi and Theological Printing Press Ltd.

Odora-Hoppers, CA 1998. Structural violence as a constraint to African Policy Formation in the 1990s: Repositioning education in International Relations. Stockholm: Institute of International Education 
Odora-Hoppers, C \& Richards, H 2011. Rethinking Thinking: Modernity's 'Other' and the Transformation of the University, Taproot Series: Volume 1. Pretoria: University of South Africa Press.

Pohl, C \& Hirsh Hadorn, G 2006. Gestaltungsprinzipien für die Transdisziplinäre Forschung: Ein Beitrag des td-net (English translation). München: Oekom.

Pohl, C 2011. What is progress in transdisciplinary research? In Futures, 43:618-626.

Rodney, W 1981. How Europe underdeveloped Africa. Washington, DC: Howard University Press.

Walsh, C, Schiwy, F \& Gastro-Gómez, S 2002. Indisciplinar las ciencias sociales. Geopolíticas del conocimiento y colonialidad del poder. Perspectivas desde lo andino. Quito: Abya Yala.

Wilson, AN 2002. The falsification of Afrikan consciousness: Eurocentric history, psychiatry and the politics of white supremacy. New York: Afrikan World InfoSystems. 